\title{
PROBLEMS OF PRESERVATION AND TRANSMISSION OF DOMESTIC TRADITIONAL CULTURE: PHILOSOPHICAL ANALYSIS
}

\author{
(C) Maria V. Smagina, Larisa A. Tronina \\ Stavropol State Pedagogical Institute, Stavropol, Russian Federation \\ science-almanac@mail.ru
}

In a traditional society, culture performed many complex functions; the leading one was the reproduction of a traditional collectivist personality. The whole society in the process of its existence reproduced this very culture: in labor, holiday, and everyday life. A significant role in this process was played by the ability to read, translate symbolic, symbolic information into senses. That is, performing a ceremony, singing songs, placing a certain pattern or embroidery, the representative of a traditional society should always have a clear idea: why exactly this action is necessary at the moment, which sign is male and which is female. With the violation of the integrity of the traditional society, a change in lifestyle, the traditional division of responsibilities, the whole cultural landscape is changing. The meanings that were invested in rituals and objects are lost, transformed sometimes even by the next generation of cultural bearers. It, like a mirror, reflects all the modernization processes that society has experienced. The root, structural parts of the culture are also preserved in it. In this regard, the question arises, which part of the culture preserves broadcast and presents to the young generation? This dispute has repeatedly arisen among professionals and there is no unambiguous answer to it. This is connected with historical difficulties, with those severe shocks that Russian society suffered.

Key words: cultural politics, values, popular culture, ethnic culture, syncretism, traditionalism, traditional society.

\section{[М.В. Смагина, Л.А. Тронина Проблемы сохранения и трансляции отечественной традиционной культуры: философский анализ]}

В традиционном обществе культура выполняла множество сложных функций, ведущей из которых было воспроизводство традиционной коллективистской личности. Все общество в процессе своего существования воспроизводило эту самую культуру: в труде, празднике, повседневной жизни. Значительную роль в этом процессе играло умение чтения, перевода символьной, знаковой информации в смыслы. То есть, производя обряд, распевая песни, помещая определенный рисунок или вышивку, представитель традиционного общества всегда должен четко представлять: почему именно это действие необходимо в данный момент, какой знак мужской, а какой женский. С нарушением целостности традиционного общества, изменением образа жизни, традиционного разделения обязанностей меняется весь культурный ландшафт. Смыслы, которые вкладывались в обряды, предметы, теряются, трансформируются, подчас даже следующим поколением носителей культуры. В ней как в зеркале отражаются все модернизационные процессы, которые испытывало общество. В нем же сохраняются и корневые, структурные части культуры. В связи с этим возникает вопрос, какую часть культуры сохранять, транслировать и презентовать молодому поколению? Этот спор неоднократно возникал в среде профессионалов, и однозначного ответа на него нет. Связано это, не в последнюю очередь, с историческими сложностями, с теми сильнейшими потрясениями, которые перенесло российское общество.

Ключевые слова: культурная политика, ценности, народная культура, этническая культура, синкретизм, традиционализм, традиционное общество.

Maria V. Smagina - Ph.D. in Sociology, Associate Professor, Stavropol State Pedagogical Institute, Stavropol, Russian Federation.

Larisa A. Tronina - Ph.D. (Advanced Doctorate) in Philosophy, Associate Professor, Stavropol State Pedagogical Institute, Stavropol, Russian Federation.

Смагина Мария Викторовна - кандидат социологических наук, доцент, Ставропольский государственный педагогический институт, г. Ставрополь, Российская Федерация. 
Тронина Лариса Анатольевна - доктор фрилософфских наук, доцент, Ставропольский государственный педагогический институт, г. Ставрополь, Российская Федерация.

It is important to emphasize the controversial role played by Soviet power in the history of Russian traditional culture. On the one hand, we owe it for the preservation of a large number of folk crafts, which almost died during all trials in the early twentieth century. This is logical, since the state of workers and peasants was obligated to support the culture of the peasants and workers. It meant that in general the entire artistic culture of the new society was supposed to function, be preserved and develop precisely as a folk: firstly, being folk in its origins and foundations; secondly, in its focus on serving the people of the country building communism; thirdly, in terms of accessibility to the masses, prevalence, and mass popularity. All this determined the attention of the Soviet government to the preservation and use of folk art culture. As well as attitude to the new in the state and development of folk art.

On the other hand, one of the priority areas of the Bolshevik policy was the fight against religion, which was one of the foundations of the spiritual culture of the people. Moreover, here it was not so significant what kind of people: a Russian or a foreigner who professed Islam or Buddhism, since all religions, their worshipers and ministers were equally subjected to persecution.

At the same time, it was repeatedly emphasized that one of the most important tasks of Soviet society was its modernization, the creation of a new society, and the destruction of traditional foundations. It was traditional nationality that was the basis of the former system, its ideological core, which also included Orthodoxy and autocracy. In this regard, all traditional ritual was ruthlessly destroyed and supplanted by new forms, which means special cultural forms associated with the symbolic overcoming of critical situations in human life i.e. birth, initiation, marriage, epidemics, crop failure, death. Since these rituals are an integral part of being and reflect the experience of individual and collective experience of specific events.

All this contradicted Soviet cultural policy, which can be described as state activity aimed at transforming the sphere of culture and art in a socialist spirit. The main principle was the eradication of those values that were associated with the former tsarist regime and prevented the building of a bright future, since archaism blew from them.

Therefore, the following areas can be distinguished in the cultural policy of the USSR: the active propaganda of socialist ideals, the elimination of illiteracy, the fight against religious vestiges and superstition, the formation of a model of Soviet art that is distinguished by ideology and innovation, the creation of a new everyday life. Moreover, such transformative activity was carried out in stages, and depended on the attitude of the party organs to the traditional customs and rites of the peoples of the USSR in a particular period. If until the 1930s of the 20th century, severe restrictions and persecution of all ethnic elements of culture, the supplanting of them by internationalist ideas, can be noted, then in the post-war period the authorities are striving to adapt ethnic elements of culture to the needs of the state.

In addition to religious foundations that form religious consciousness, noting "the influence of Orthodoxy on the formation and design of Russian culture" [11, pp. 39-44], many customs associated with family life and traditional roles were recognized archaic. Women involved in socialist construction were torn away from their traditional abode, escaped from the comprehensive control of husbands or fathers, and were able to independently determine and secure their future. A woman working outside the home has become the norm for the vast majority of families, even in such a traditional corner as the 
Caucasus, where special activities were held in the Soviet years, such as "a coat for every goryanka (a mountain girl)". It was organized to provide women with warm outerwear, which made it possible to participate in cooperation, to receive education, breaking away from the traditional way of life, in which a man maintained all connections with the outside world. A policy of prohibition of domestic violence and the elimination of physical punishment for all its members was also purposefully pursued.

In Central Asia and the Caucasus, they fought with a burqa, in Kalmykia and among the highlanders of the Caucasus, with a camisole, a special corset that was worn on girls during puberty and was not removed before marriage. Its task is to promote the formation of a slim figure and prevent the development of the chest and mammary glands. As hygienists proved, this custom harmed the young body, often caused the rapid development of tuberculosis. Thus, we see that Soviet power not only influenced relations within the family, destroying the traditional family, but also influenced the traditional costume, excluding from it those elements that were recognized archaic.

The value of folk art was determined by its usefulness in building socialism, a new society. Party and state leaders proceeded from the fact that although folklore expresses the ideology and artistic tastes of the working people, it is nevertheless necessary to distinguish between the advanced, the progressive and the backward, the patriarchal. According to V.I. Lenin, knowledge of folk art is useful for understanding folk psychology. In addition, this is creativity itself, which he noted in the article "The Development of Worker Choirs in Germany", for the promotion of socialism. In any case, the study, preservation and use of folk culture, its achievements in Soviet times became practically urgent. This affected the fate of folk art and performance in post-revolutionary Russia.

On the one hand, the attention of the Soviet government to folk art culture contributed to the preservation of its rich heritage, the extension of the vitality of folk traditions in art. On the other hand, this same attention was expressed in political, ideological, organizational pressure on the entire sphere of folk culture. Under such pressure, the actual nationality was gradually supplanted, being replaced by its ersatz, imitations, at best, by semi-official forms of existence specially organized by the state.

With the advent of Soviet power, the work of theoretical understanding of folklore was continued, acquiring a new revolutionary spirit and scale. On the developed theoretical basis, practical research was organized, and in the Soviet state they began work on the collection of specific monuments of the spiritual and material parts of traditional culture. Collection and studies were carried out within the framework of the country's integrated system, which included central and regional levels. Folklore expeditions were organized, whose activities were coordinated by experienced specialists from the Academy of Sciences and the Houses of Folk Art. The Institute of Russian Literature of the USSR Academy of Sciences played one of the leading roles in this matter. Teachers and students of historical and philological faculties were involved in the work.

The research space was constantly expanding. So, if in the North-West of Russia in the nineteenth and first half of the twentieth centuries, the folklore of the Russian North was actively collected, then from the 60s. The twentieth century began to attract more attention from other regions. In Veliky Novgorod, at the Department of Russian Literature of the Pedagogical Institute (later Novgorod State University), since 1958, local folklore has been systematically collected, the work that has begun continues to the present.

In many Russian regions, recordings of folklore texts and melodies, descriptions of dance structures, and the collection of works of folk art were made. New opportunities were opened with the use of new technology: voice recorders, tape recorders, photos, movie cameras and video cameras. The hard and meticulous work of collectors made it possible to concentrate in the archives of various levels the true wealth of the folk culture, demonstrating not only all its diversity and wealth, but also the development processes 
and dynamics. All this created the basis for serious scientific analysis, preparation of publications.

At the same time, folk art culture was preserved not only as archival and museum values, but also in its effectiveness, which was ensured by the creation of a system of special organizations and institutions in post-revolutionary Russia. A network of clubs (rural and urban), houses and palaces of culture, including houses of folk art, which became the basis for folk ensembles, folk instrument orchestras, choral and dance groups, studios and folk art clubs, was deployed throughout the country. Similar forms of work were organized not only at district houses of culture, but also unfolded at large agricultural and industrial enterprises, in army formations, higher educational institutions, and secondary specialized educational institutions.

Festivals and competitions of folk art were constantly held in the country. In clubs, houses and palaces of culture, however, folk art gradually became more and more tangibly represented in the system of so-called amateur performances, derived from amateurism striving for professionalism.

Domestic scholars of folklore drew attention to the fact that coexist, complementing each other, types of leisure art activities that go back to the traditions of folk (folklore) creativity and follow the system, the organizational and creative principles of professional art. For example, in the framework of the creative work of a higher educational institution, two choirs could function successfully at once: folk and academic, differing both in the manner of performance and in their repertoire and style. Moreover, professionalism, or at least the desire for it, will be equally characteristic of both teams.

As a result, folklorism supplanted genuine folklore. Folk culture, which lost its living connection with life, also lost its other systemic attributes. Living conditions changed: the presence of a scene and a spectator, as an outside observer, significantly transformed the performing style. The training was based on musical notation, singing skills were no longer directly transferred from one performer to another. The professional growth of individual performers and groups was accompanied by the loss of living tribal signs of folklore.

As a result of the development of this tendency, literary processing of texts of folk tales, academic processing of texts and parts of songs were performed, the average versions of the dance were reproduced, brought to the highest level of performing skills, but devoid of regional features, local traditions. They created masterly samples of Russian dance or horovod (round dance), the most exquisite drawing, song and dance ensembles of the Soviet Army, "Birch", embodying a certain average, generalized image of Russian folk song and dance art, which in their interpretation no longer had any regional features. Folk choirs are the brainchild of a new time, it does not need fields and huts, and its element is a stage, screen, and holiday. This is not life. This is not folklore. This is folklorism.

Unfortunately, an impersonal tradition was not only characterized by an increase in professionalism, but was also accompanied by the proliferation of cliches, which were not only reproduced in concert activity, but also penetrated into everyday life, crowding out genuine samples in their natural environment. Similar processes were noted all over the world, where the folk tradition was transformed in cities under the influence of industrialization processes, but in the Soviet reality, the factor of ideological pressure was also added. What is preserved exists in the secondary tradition and is filled with new meanings, changing meaningfully. The semantic, substantial change in the folk art culture in postrevolutionary Russia was significant. It was caused in some ways by the new realities of life, in something by political and ideological pressure.

It is important to mention that the noted trend associated with the displacement of traditional culture from everyday life, the loss of crafts, various types and monuments of folklore, has a worldwide sound. Programs and conventions developed by international organizations such as UNESCO are devoted to the fight against this problem, impoverishing 
the world cultural heritage. At the federal level, similar programs were created in our country aimed at preserving and maintaining the popular culture. In the Stavropol Territory, a local program to support and preserve folk culture has been developed and is operating.

The All-Russian project "Cultural normative of a schoolchild", whose Stavropol region has become a pilot region, has a role to play in this direction. To a certain extent, it resembles the TRP system, however, it transfers the principle of activity to the field of culture, including folklore. It provides closer interaction between regional ministries of culture and education and creates the conditions for mass acquaintance with folk culture, especially at the school level. The recommendations emphasize such important principles of the organization of work within its framework as a systematic, interactive, as well as an activitybased approach that defines "... the quality of a person and the ability of social subjects to purposefully interact with the environment" [10, pp. 282-284], "the complex interaction of various types of social communication" [2, pp. 5-10].

The dual role in preserving traditional folk culture is played by tourism, which has been actively developed in the last decade. On the one hand, it often stimulates the mass import of Chinese consumer goods, which the local craft cannot withstand, applied art, which always requires a lot of time, is associated with complex, lengthy technological operations. Often, in competition with it, traditional ornaments are simplified, craftsmen, in pursuit of commercial benefits, modernize materials, replacing local natural ones with imported ones, with synthetic ones. On the other hand, it is impossible not to note the beneficial effect of ethnographic tourism on the attention of local communities to folk culture. Thanks to the spread of this type of tourism, large ethnic festivals are possible, and folk traditions are being addressed.

Researchers have identified some of the most promising and relevant areas in the preservation of popular culture. First of all, this is the actualization of the problem in the media, including social networks, where you can present the work of teams in new formats, the problems of conservation, and find new points of interaction between interested participants. Another process that is gaining popularity is the ethnopedagogization of education, accompanied by the creation of a special environment, ethnocultural space. Another promising direction, fundamental for the preservation of folk culture, is interaction with the family, information and educational work carried out by various agents and designed to return the folk culture to the fold from the system of basic and additional education in the environment of its natural existence - to the family. At the same time, acquaintance with it must be carried out as with a complex phenomenon, not to tear off the dance artificially from singing or other folklore samples. This syncretism is a generic sign of this type of culture.

Thus, the task of modern teachers is not to empirically, but scientifically and creatively convey the true foundations of traditional culture and convey them in a true, not distorted form to their students and pupils, endowing them with a national character. The national character can be recognized by studying the national education system [3, pp. 28-34]. It is necessary to organize a system of upbringing and education based on a scientific study of the forms, methods, directions and mechanisms of personality development [9, pp. 15-18]. Dialogue and the interaction of cultures provide "... fostering a positive attitude towards cultural differences" [4, pp. 7-10].

At the present stage of social development, approaches to the problem of preserving and reviving traditional culture in the scientific community are ambiguous. Professor A.S. Karmin, for example, speaks out in favor of preserving the tradition, considering it not viable, which has gone irretrievably into the past. Trying to revive the forgotten customs of bygone days and the signs of antiquity is deep i.e. it means not to call for a rise, but for the decline of the country's cultural level. The ethnic culture of the past is increasingly moving to museums. It must be known and studied, but live in a modern culture. "Culture is under- 
stood as the inner essence of human ideas ..." [14, pp. 3-9]. "Culture is an essential characteristic of the social sphere of society; it is inseparable from human social activity" [5, pp. 74-78].

As against this view, Professor A. M. Mehnetsov presented his assessment. "The data of modern science indicate that folk traditions, traditions of the material and spiritual life of the people, keeping on the basis of continuity the most important principles and sides of their historical experience, developing over many centuries, have a natural and flawless adaptation mechanism in the changing objective conditions of their existence. The traditions of folk culture, harmonizing the properties of conservatism and constant renewal in their laws, are built into a historically multilayered and, at the same time, integral system in which past experience, if necessary, can be claimed and recreated "[7, p. 45].

Both positions have their supporters and deep, serious reasoning. It is necessary to approach this issue with great responsibility, reviving the cultural-creating, social, moral, spiritual principles of traditional culture and preserving in the museums and scientific journals the customs and traditions that, as Professor A.S. Carmine says, you need to know and study, but not return, thereby discarding the development of culture and civilization far back into the darkness of the pagan centuries.

A similar question is even more acute and difficult in such a complex, multinational region as the North Caucasus, where it is impossible to put emphasis exclusively on Russian folk culture, where there were their own rich Slavic, mountainous, nomadic traditions that have different religious, economic and linguistic backgrounds closely intertwined, and continuing to maintain their identity. At the same time, the problems that confronted Russian culture in the Soviet years were no less acute for other national traditions. The situation is aggravated by the active re-Islamization, which requires an even more balanced, accurate and competent approach when referring to traditional culture [16].

As a result, it can be noted that folk culture underwent significant transformations during the 20th century. It ceased to exist in its original, natural state, since under the conditions of industrialization its natural environment of reproduction, the traditional society, was lost. On the one hand, the Soviet government, showing attention to culture, tried to fix and support it, carried out a great ethnographic work, made significant efforts to save the traditional crafts [13, p. 81], one way or another determining the socio-cultural development of society [6, pp. 123-128]. On the other hand, struggling with religion and the remnants of traditionalism, whole layers were destroyed in folk culture, ritualism and the semantics of images were transformed. Organizing the activities of folklore creative groups at institutions, houses of culture, set a higher standard of artistic professionalism. Culture began to lose its regional characteristics, identity, generic traits, degenerating into folklorism, characterized by a kind of averaged, generalized image. Knowledge and understanding of folk culture in such conditions has become scarce, especially after the 1990s. The twentieth century, when, in principle, the state could not allocate funds to support culture. All this created the prerequisites for the formation of two opposing approaches to the issue of functioning and broadcasting of folk culture.

Some researchers believe that it is futile to revive it, it should be studied and knowledge of it among a narrow circle of specialists: folklorists, museum workers, ethnographers. Another part of the researchers argues that transmitting a new culture to new generations, albeit in a modified form, is extremely important. It is necessary to reproduce it very carefully, reverently and carefully, and a great role is played by professionals who, in the form of holidays, festivals, would acquaint new generations with the great national heritage that contributes to the realization of historical continuity. Historical continuity as the highest value "... is based on a real presence ... in the human mind" [14, pp. 31-34], is closely connected with historical memory [15, pp. 41-47]. This ensures the interaction of basic and additional education, guaranteeing the proper level and quality of the resulting 
cultural product, which contributes to the "dialogue of cultures in the context of the development of modern civilization" [12, pp. 145-160], which defines modern sociality [1, pp. 168-177].

\section{Лumepamypa}

1. Бакланова О.А., Бакланов И.С. Современная российская социальность в контексте социального конструкционизма // Вопросы социальной теории. 2015. Т. 7. № 1-2. С. 168-177.

2. Бакланова О.А., Бакланов И.С. Контуры типологического исследования социальности современного общества // Известия Саратовского университета. Новая серия. Серия: Философия. Психология. Педагогика. 2014. Т. 14. № 2-1. С. 5-10.

3. Говердовская E.В. Социокультурные и этнологические особенности региона основа модернизации высшего образования на Северном Кавказе // Ученые записки университета им. П.Ф. Лесгафта. 2007. № 7. С. 28-34.

4. Говердовская Е.В. Особенности проектирования образовательного пространства высшей школы в поликультурном регионе // Экономические и гуманитарные исследования регионов. 2014. №4. С. 7-10.

5. Ерохин А.М. Социально-философские аспекты развития культурной сферы общества // Экономические и гуманитарные исследования регионов. 2016. № 1. C. 74-78.

6. Ерохин А.М. Научно-информационный аспект исследования социокультурного развития общества в области культуры и искусства // Экономические и гуманитарные исследования регионов. 2015. № 2. С. 123-128.

7. Еәле Л.Ю. Традиционная культура: основные подходы к исследованию // Вестник Кемеровского государственного университета культуры и искусства. Ч.II. 2014. №29. C. 43-49.

8. Ивушкина E.Б., Дашкова E.B. Проблема коммуникационного познания // Экономические и гуманитарные исследования регионов. 2010. № 4. С. 85-94.

9. Лобейко Ю.А. Социально-педагогический аспект активности личности в системе общественного развития // Экономические и гуманитарные исследования регионов. 2015. №1. С. 15-18.

10.Лобейко Ю.А. Социальная активность личности в обществе: социальнопедагогические аспекты формирования // European Social Science Journal. 2014. №7-2(46). С. 282-284.

11. Матяш Т.П., Несмеянов Е.Е. Православный тип культуры: идея и реальность // Гуманитарные и социально-экономические науки. 2015. № 3 (82). С. 39-44.

12. Несмеянов E.Е. «Цивилизация молодых»: идея и реальность // Гуманитарные и социальные науки. 2013. № 6. С. 145-160.

13. Спирина М.Ю. Традиционная культура в современном социокультурном пространстве // Вестник Мариупольского государственного университета. Серия. Философия. 2014. Выпуск 8. С. 80-85.

14. Berkovskiy V., Tronina L. Social and historical aspect of interaction of ethnic culture and personality in the context of public development // Научный альманах стран Причерноморья. 2019. №1 (17). С. 3-9.

15. Kuleshin M., Leonova N., Nemashkalov P. Historical consciousness as a part of national consciousness: to the problem statement of the research // Научный альманах стран Причерноморья. 2019. №1 (17). С. 41-47. 
16. Nesmeyanov E.E., Rudenko A.M., Kotlyarova V.V. Sociocultural analysis of cyberterrorism in social nets within the problems of information safety of Russian society // Научный альманах стран Причерноморья. 2015. № 4. http://science-almanac.ru

\section{References}

1. Baklanova O.A., Baklanov I.S. Sovremennaya rossiyskaya sotsialnost v kontekste sotsialnogo konstruktsionizma. Voprosy sotsialnoy teorii. [Modern Russian sociality in the context of social constructionism. Questions of social theory]. 2015. V. 7. No. 1-2. pp. 168-177 (In Russian).

2. Baklanova O.A., Baklanov I.S. Kontury tipologicheskogo issledovaniya sotsialnosti sovremennogo obshchestva. Izvestiya Saratovskogo universiteta. Novaya seriya. Seriya: Filosofiya. Psikhologiya. Pedagogika. [Contours of a typological study of the sociality of modern society. News of the Saratov University. New series. Series: Philosophy. Psychology. Pedagogy]. 2014. V. 14. No. 2-1. pp. 5-10 (In Russian).

3. Goverdovskaya E.V. Sotsiokulturnyye i etnologicheskiye osobennosti regiona - osnova modernizatsii vysshego obrazovaniya na Severnom Kavkaze. Uchenyye zapiski universiteta im. P.F. Lesgafta. [Sociocultural and ethnological features of the region are the basis for the modernization of higher education in the North Caucasus. Scientific notes of the University. P.F. Lesgaft]. 2007. No. 7. pp. 28-34 (In Russian).

4. Goverdovskaya E.V. Osobennosti proyektirovaniya obrazovatelnogo prostranstva vysshey shkoly $v$ polikulturnom regione. Ekonomicheskiye i gumanitarnyye issledovaniya regionov. [Features of designing the educational space of a higher school in a multicultural region. Economic and humanitarian studies of regions]. 2014. No. 4. pp. 7-10 (In Russian).

5. Erokhin A.M. Sotsialno-filosofskiye aspekty razvitiya kulturnoy sfery obshchestva. Ekonomicheskiye i gumanitarnyye issledovaniya regionov. [Socio-philosophical aspects of the development of the cultural sphere of society. Economic and humanitarian studies of the regions]. 2016. No. 1. pp. 74-78 (In Russian).

6. Erokhin A.M. Nauchno-informatsionnyy aspekt issledovaniya sotsiokulturnogo razvitiya obshchestva $\mathrm{v}$ oblasti kultury $\mathrm{i}$ iskusstva. Ekonomicheskiye i gumanitarnyye issledovaniya regionov. [The scientific and informational aspect of the study of socio-cultural development of society in the field of culture and art. Economic and humanitarian studies of the regions]. 2015. No. 2. pp. 123-128 (In Russian).

7. Egle L.Yu. raditsionnaya kultura: osnovnyye podkhody $\mathrm{k}$ issledovaniyu. Vestnik Kemerovskogo gosudarstvennogo universiteta kultury i iskusstva. [Traditional culture: basic research approaches. Bulletin of the Kemerovo State University of Culture and Art]. Part II. 2014. No. 29. pp. 43-49. (In Russian).

8. Ivushkina E.B., Dashkova E.V. Problema kommunikatsionnogo poznaniya. Ekonomicheskiye i gumanitarnyye issledovaniya regionov. [The problem of communication knowledge. Economic and humanitarian studies of the regions]. 2010. No. 4. pp. 85-94. (In Russian).

9. Lobeiko Yu.A. Sotsialno-pedagogicheskiy aspekt aktivnosti lichnosti v sisteme obshchestvennogo razvitiya. Ekonomicheskiye i gumanitarnyye issledovaniya re- 
gionov. [The socio-pedagogical aspect of personality activity in the system of social development. Economic and humanitarian studies of the regions]. 2015. No. 1. pp. 15-18 (In Russian).

10.Lobeiko Yu.A. Sotsialnaya aktivnost lichnosti v obshchestve: sotsialnopedagogicheskiye aspekty formirovaniya. [The social activity of the individual in society: socio-pedagogical aspects of formation]. European Social Science Journal. 2014. No. 7-2 (46). pp. 282-284 (In Russian).

11. Matyash T.P., Nesmeyanov E.E. Pravoslavnyy tip kultury: ideya i realnost. Gumanitarnyye i sotsialno-ekonomicheskiye nauki. [Orthodox type of culture: idea and reality. Humanitarian and socio-economic sciences]. 2015. No. 3 (82). pp. 39-44 (In Russian).

12. Nesmeyanov E.E. «Tsivilizatsiya molodykh»: ideya i realnost. Gumanitarnyye i sotsialnyye nauki. ["Civilization of the young": idea and reality. Humanities and social sciences]. 2013. No. 6. pp. 145-160 (In Russian).

13. Spirina M. Yu. Traditsionnaya kultura v sovremennom sotsiokulturnom prostranstve. Vestnik Mariupolskogo gosudarstvennogo universiteta. Seriya. Filosofiya. [Traditional culture in modern sociocultural space. Bulletin of Mariupol State University. Series. Philosophy]. 2014. Issue 8. pp. 80-85 (In Russian).

14. Berkovskiy V., Tronina L. Social and historical aspect of interaction of ethnic culture and personality in the context of public development. Science almanac of Black sea region countries. 2019. №1 (17). pp. 3-9.

15. Kuleshin M., Leonova N., Nemashkalov P. Historical consciousness as a part of national consciousness: to the problem statement of the research. Science almanac of Black sea region countries. 2019. No.1 (17). pp. 41-47.

16. Nesmeyanov E.E., Rudenko A.M., Kotlyarova V.V. Sociocultural analysis of cyberterrorism in social nets within the problems of information safety of Russian society. 2015. No. 4. 